\title{
Lipoprotein types, serum cholesterol, and ABO blood groups
}

\author{
A. POLYCHRONOPOULOU, C. J. MIRAS, AND D. TRICHOPOULOS \\ Departments of Biochemistry and of Hygiene and Epidemiology, Athens University Medical School, Athens 609
}

\section{SUMMARY}

Among 48 cases with primary hyperlipoproteinaemia (HLP) type II, $27(56 \%)$ were of blood group A, while among 35 cases with primary HLP type IV, only $11(31 \%)$ were of this blood group. The difference is large and statistically significant. Since serum cholesterol levels are fairly or very high in HLP type II, it is suggested that the known weak assuciation between blood group $\mathbf{A}$ and serum cholesterol is a reflection of a more direct association between blood groups and lipoprotein types.

\section{INTRODUCTION}

In a number of studies it has been found that healthy men and women of blood group $A$ have higher mean serum cholesterol levels than those of groups $\mathbf{O}$ or B (Langman, Elwood, Foote, and Ryrie, 1969; Mayo, Fraser, and Stamatoyannopoulos, 1969; Oliver, Geizerova, Cumming, and Heady, 1969; Hagerup, Hansen, and Skov, 1972). In the modified (Beaumont et al., 1970) classification system of Fredrickson, Levy, and Lees (1967), type II hyperlipoproteinaemia (which will be referred to as HLP type II or simply as type II) is characterized by fairly or very high cholesterol levels, while cholesterol levels in type IV are usually normal or only slightly elevated. Therefore, a higher proportion of group A persons should be expected among cases with HLP type II than among cases with type IV or individuals with normal serum lipids. The following are the findings from an investigation of a sample of cases with primary hyperlipoproteinaemia.

\section{SubJeCtS AND MeThods}

The sample studied was not representative of any defined population, but the selection criteria were unrelated to $\mathrm{ABO}$ blood groups. Of persons referred to the Department of Biochemistry, Athens University Medical School (mainly from the University Clinics of King Paul's General Hospital in Athens), cases were included in the study sample if they met the criteria of primary hyperlipoproteinaemia of the modified (Beaumont et al., 1970) classification $\subseteq$ system of Fredrickson et al. (1967). Patients with diabetes and thyroid, liver or renal diseases were excluded, as were relatives of any case already accepted. The subjects should not be on a diet nor take medications known to affect plasma lipid or lipoprotein concentrations. Ninety-two persons $\vec{T}$ were included in the study sample, 58 males and $\frac{1}{O}$ 34 females, whose ages ranged between 6 and 68 years with a mean of 46.5 years. Several cases had coronary or dermatological manifestations while the others were clinically normal.

Fasting serum cholesterol and triglyceride deter minations were made respectively by the modified method of Henly (Henry, 1964) and the modified method of Carlson and Wadström (Henry, 1964). The electrophoresis of lipoproteins was performed on agarose gel according to Cawley's (1969) method. ABO blood groups were determined by standard agglutination techniques.

Of the 92 cases with primary hyperlipoproteinaemia, 48 were of type II, 35 of type IV, 3 of type V, and 1 of type $I$. The remaining 5 were unclassifiable. In the statistical analysis blood groups $\mathrm{B}$, $A B$, and $O$ were combined and only cases of types II and IV were considered. As age is not related to ABO groups, and the mean age was practically the same in types II and IV $(46.4$ and 46.7 years respectively), comparisons were not adjusted for age.

\section{RESULTS}

The distribution of cases by HLP type and ABO group and the mean serum cholesterol in relation to the HLP type and ABO groups are shown in Tables $C$ $I$ and II. The proportion of group A persons is higher in type II $(56.3 \%)$ than in type IV $(31.4 \%)$ and, although the numbers are small, the difference $\Phi$ is not likely to be due to chance ( $\chi^{2}$ with Yates' $\stackrel{\mathcal{O}}{\rightarrow}$ correction and one degree of freedom $4.07 ; P<$ 0.05 ). 
TABLE I

CASES OF PRIMARY HYPERLIPOPROTEINAEMIA, BY HLP TYPE AND ABO BLOOD GROUP, AND MEAN ( \pm SE) SERUM CHOLESTEROL BY ABO BLOOD GROUP

\begin{tabular}{|c|c|c|c|c|c|c|c|}
\hline & & & \multicolumn{5}{|c|}{ Blood Group } \\
\hline \multicolumn{3}{|c|}{ Type of HLP } & $\mathbf{A}$ & B & $\mathbf{A B}$ & o & $\begin{array}{c}\text { All } \\
\text { Groups }\end{array}$ \\
\hline $\begin{array}{l}\text { II } \\
\text { IV } \\
\text { Both }\end{array}$ & $\begin{array}{l}. \\
\ldots\end{array}$ & $\begin{array}{l}\because \\
. .\end{array}$ & $\begin{array}{l}27 \\
11 \\
38\end{array}$ & $\begin{array}{l}2 \\
6 \\
8\end{array}$ & $\begin{array}{l}3 \\
1 \\
4\end{array}$ & $\begin{array}{l}16 \\
17 \\
33\end{array}$ & $\begin{array}{l}48 \\
35 \\
83\end{array}$ \\
\hline \multicolumn{3}{|c|}{$\begin{array}{l}\text { Mean serum } \\
\text { cholesterol } \\
(\mathrm{mg} / 100 \mathrm{ml}) \\
( \pm \text { SE) }\end{array}$} & $\begin{array}{c}359 \cdot 7 \\
(14 \cdot 7)\end{array}$ & $\begin{array}{l}285 \cdot 6 \\
(32 \cdot 0)\end{array}$ & $\begin{array}{c}367 \cdot 5 \\
(45 \cdot 3)\end{array}$ & $\begin{array}{l}332 \cdot 4 \\
(15 \cdot 8)\end{array}$ & $\begin{array}{r}342 \cdot 1 \\
(9 \cdot 9)\end{array}$ \\
\hline
\end{tabular}

TABLE II

MEAN SERUM CHOLESTEROL $(\mathrm{mg} / 100 \mathrm{ml})$, BY HLP TYPE AND ABO BLOOD GROUP

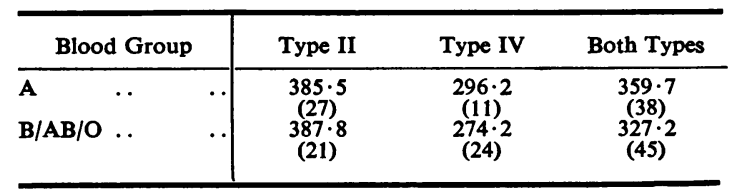

Figures in parentheses show number of cases.

Interaction is not significant $(P>0 \cdot 20)$.

Difference (Group A-Groups B/AB/O)

Unadjusted
Adjusted

\section{Discussion}

It has been assumed so far that the relationship between ABO groups and cholesterol level is the direct one, and that between ABO groups and hyperlipoproteinaemic types is secondary. However, in examining our findings, two points seem to indicate the opposite. First, the difference in the proportion of cases of group A between types II and IV is too large to be considered as a reflection of the relationship between $\mathrm{ABO}$ groups and cholesterol, since the latter is not a strong one (Langman et al., 1969; Mayo et al., 1969; Oliver et al., 1969; Hagerup et al., 1972). Second, mean cholesterol in type IV, although clearly lower than in type II, is nevertheless higher than that in the general Greek population (Keys, 1969), even though the proportion of group A persons in HLP type IV (31.4\%) is not higher than in the general population $(37 \%$ to $40 \%$ ) (Gardikas, 1963; Valaoras, 1970).

To explore further whether the ABO groups are related more directly to lipoprotein types than to serum cholesterol, we examined the relationship between ABO groups and serum cholesterol separately for types II and IV. It can be seen in Table II that the difference of mean serum cholesterol between group $A$ and all other groups
$(+32 \cdot 5 \mathrm{mg} / 100 \mathrm{ml})$ is substantially reduced $(+7 \cdot 2$ $\mathrm{mg} / 100 \mathrm{ml}$ ) when the effect of the HLP type is controlled in the statistical analysis (Snedecor and Cochran, 1967). On the other hand, matching for cholesterol level, in categories sufficiently broad to allow an acceptable degree of cross-matching, has little effect on the strength of the association between lipoprotein types and ABO blood groups (crude relative risk $=2 \cdot 8$; adjusted summary relative risk from $2 \cdot 1$ to $3 \cdot 8$, depending on the matching categories adopted) (Mantel and Haenszel, 1959).

The above appear to us to provide evidence that ABO blood groups are more directly related to hyperlipoproteinaemic types than to serum cholesterol levels. If other studies supported the view presented here, credence would be added to the classification of hyperlipidaemias according to the lipoprotein patterns (Beaumont et al., 1970; Fredrickson et al., 1967).

This work was supported by a grant from the (Greek) Office of Scientific Research and Development.

\section{REFERENCES}

Beaumont, J. I., Carlson, L. A., Cooper, G. R., Fejfar, Z., Fredrickson, D. S., and Strasser, T. (1970). Classification of hyperlipidaemias and hyperlipoproteinaemias. Bull. Wld. Hith Org., 43, 891.

CAWLEY, L. P. (1969). Electrophoresis and Immunoelectrophoresis, p. 264. Little Brown, Boston.

FredRICKSON, D. S., LeVY, R. I., and LeES, R. S. (1967). Fat transport in lipoproteins-An integrated approach to mechanisms and disorders. New Engl. J. Med., 276, 32-44, 94-103, 148-156, 215-226, 273-281.

Gardikas, C. (1963). Haematology, p. 449. Parisianos, Athens.

Hagerup, L., Hansen, P. F., and Skov, F. (1972). Serum-cholesterol, serum-triglyceride and $\mathrm{ABO}$ blood groups in a population of 50-year-old Danish men and women. Amer. J. Epidemiol., 95, 99.

Henry, R. J. (1964). Clinical Chemistry, pp. 855, 866. Harper and Row, New York.

KEYS, A. (1969). Cardiology-the essentiality of prevention. Minn. Med., 52, 1191.

Langman, M. J. S., Elwood, P. C., Foote, J., and RYRIE, D. R. (1969). ABO and Lewis blood-groups and serum-cholesterol. Lancet, 2, 607.

Mantel, N. and Haenszel, W. (1959). Statistical aspects of the analysis of data from retrospective studies of disease. J. nat. Cancer Inst., 22, 719.

Mayo, O., Fraser, G. R., and Stamatoyannopoulos, G. (1969). Genetic influences on serum-cholesterol in two Greek villages. Human Heredity, 19, 86. 
Oliver, M. F., Geizerova, H., Cumming, R. A., and HEADY, J. A. (1969). Serum-cholesterol and ABO and Rhesus blood-groups. Lancet, 2, 605.

SNEDECOR, G. and COCHRAN, W. (1967). In Statistical Methods, 6th edition, p. 483. Iowa State University Press, Ames, Iowa.
VALAORAS, V. G. (1970). Bio-social characteristics of Greek students. Proc. Athens med. Soc., p. 68.

Address for correspondence: D. Trichopoulos, M.D.,

Department of Hygiene and Epidemiology, Athens University Medical School, Athens 609, Greece 